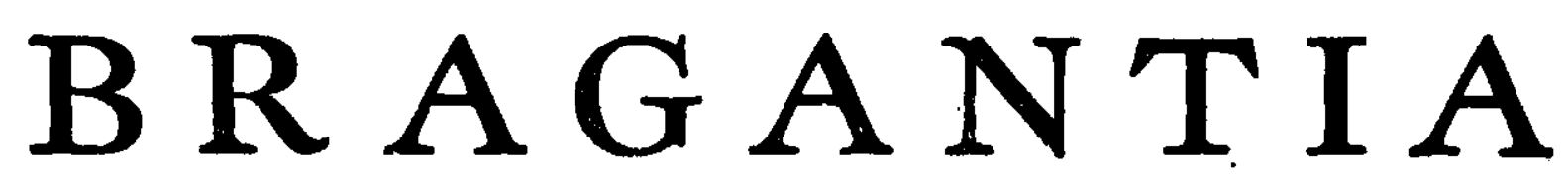

Boletim Técnico da Divisão de Experimentação e Pesquisas I N S T I T U TO A GRONÔ M I CO

Vol. 3

Campinas, Abril de 1943

N. 4

\title{
ALGUNS FUNGOS DO CERRADO
}

(Com quinze figuras no texto e dez coslampas)

A. P. Viégas

Os cerrados, a-pesar da sua aparente monotonia, são, talvez, na florística brasileira, das mais ricas áreas em espécies de fungos parasíticos. Assim, o nosso ponto de vista está em conflito com o exarado por Warming (1), o emérito perscrutador da sociologia das plantas de Lagoa Santa. Escreveu êle que uma das caraterísticas do cerrado é a sua pobresa em fungos. Se, por um lado, a generalizaçäo do botânico dinamarquês possa ser atenuada, recorrendo ao mui inieliz vêso de tomar como sinônimos os vocábulos cogumelo e fungo, termos êsses diferent:ss entre si já pela amolitude do definido, já pela signiíicação, mesmo assim a flora micológica parasítica dêsse "habitat" alcança posição invejável aos demais, no referente ao número, na complexibilidade estrutural e morfológica, na especialização, adaptação e na constância da distribuição das espécies. Ém tôdas as épocas do ano são um repositório inexhausto, carreando, do nordeste brasileiro até as lindes do Paraná, os reflexos intrigantes da caatinga.

Vejamos alguns fungos do cerrado paulista e mineiro.

\section{NECTRIA ERYTHROYYLIFOLIE N. SP.}

Em 8 de abril de 1936, os srs. Gláuco Pinto Viégas, professor Henrique de Melo Barreto e H. P. Krug coletaram, nas vizinhanças da Lagoa Santa, em Minas Gerais, um belíssimo fungo sôbre fôlhas coríaceas e espêssas de Erythroxylum suberosum St. Hil.

Ao revermos o herbário micológico do Instituto Agronômico, topamos com êsse material, e ficamos deveras perplexos, motivo porque resolvemos procurá-lo nos cerrados de Mogí-Mirim, próximos de Campinas. Fomos felizes em nossas buscas, pois nos foi dado colhêr, por várias vêzes, material em estado fresco para investigações mais cuidadosas de laboratório. Também, nas vizinhanças de Belo Horizonte, tivemos a oportunidade de encontrar a mesma espécie, sôbre o mesmo suscetível acima 
assinalado, bem como constatá-lo igualmente sôbre fôlhas de Erythroxylum campestre St. Hil. As determinações das espécies de Erythroxylacea, devemo-las à gentileza do botânico patrício prof. Henrique de Melo Barreto, conhecedor profundo da flora do Brasil central.

Estudemos primeiramente 0 material coletado em 1936, proveniente de Lagoa Santa. Está arquivado sob número 1919 no herbário do Instituto Agronômico, e dêle fizemos o tipo de Necuria erythroxylifolize.

Examinando-se, especialmente as páginas superiores do limbo de Erythroxylum suberosum St. Hil., observam-se lesões pardo-avermelhadas, circulares, esparsas ou coalescentes, de diâmetro assás variável. Formando como que um subículo esbranquiçado por sôbre as lesões, observa-se, especialmente sob a lupa, um micélio denso, emaranhado, efuso, semelhante ao de espécies de Erysiphales. Sôbre êsse tapete é que se aninham os peritécios do fungo (Est. I). As hifas componentes do tapete ou subículo, são, de início, hialinas, de paredes delicadas, sep-

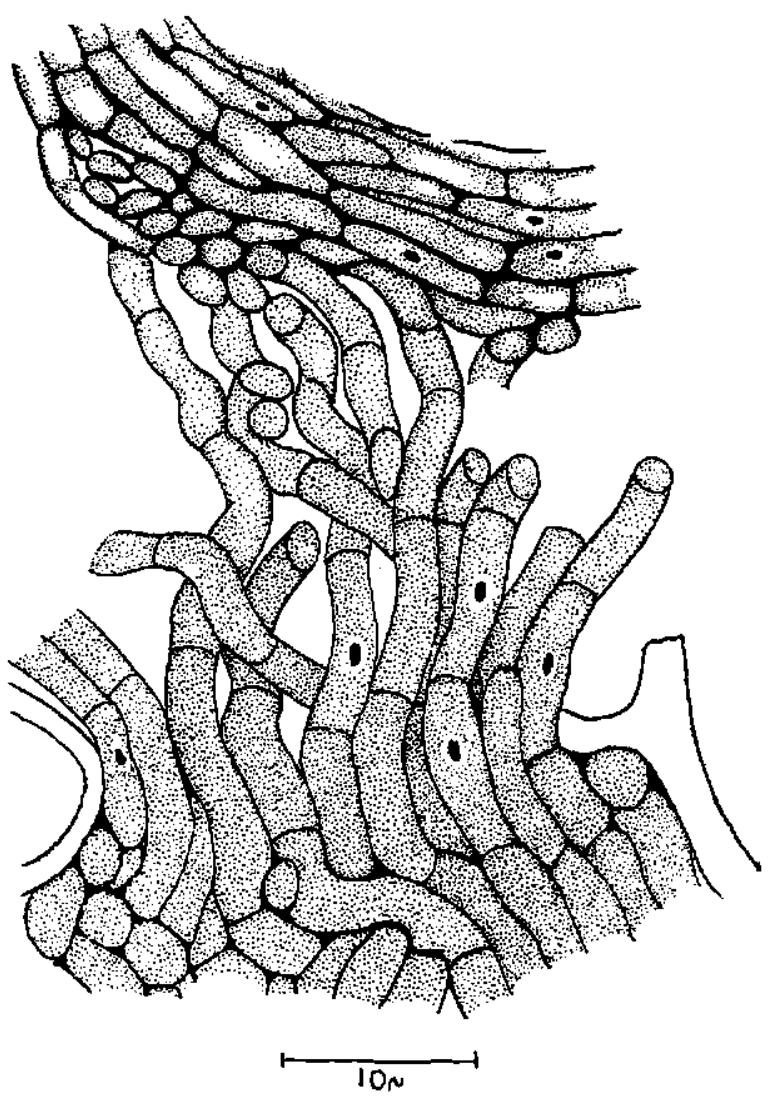

Fig. 1. tadas, uninucleadas e se ramificam abundantemente. À maturidade tornamse um tanto fuscas. Medem 4-4,5 $\mu$ de diâmetro. Quando cortamos transversalmente fôlhas atacadas, verificamos que as hifas provinham das profundezas do parênquima, ganhando o exterior através das aberturas estoma. tais teito pequenos tufos brancos, tufos êsses que não tardavam a exibir seus elementos decumbentes sôbre a página superior do limbo. Êsses elementos hifais acabam por fundir-se entre si, tormando a estrutura que indicamos pelo nome de subículo. De início, apenas poucas hifas passam através dos orifícios dos estômatos, mas, à maturidade, isto é, nas lesões mais idosas, as aberturas estomatais não resistem à evasão das hifas, pelo que se abrem, rasgando-se irregularmente (Fig. I do texto), arrebitando e revirando os seus bordos. Os filamentos hifais encontrados no interior das fôlhas parasitadas são intercelulares, septados, hialinos, uninucleados como as hifas que se dirigem para o exterior. Ramificamse abundantemente por entre as células quer do parênquima lacunoso, quer do tecido imediatamente superior, em paliçada, enviando para o interior delas, haustórios típicos (Fig. 2 do texto). Os haustórios são estruturas ramificadas, indistintamente septadas, gutuladas, parecendo que cada uma de suas células é portadora de um núcleo grande. Os 
ramos dos haustórios terminam em ponta obtusa, e, ao penetrar na massa de protoplasma das células parasitadas, forçam a membrana ao mesmo tempo que ocasionam, pelas substâncias que secretam, alterações profundas dos conteúdos celulares todos. Um dos sintomas mais frizantes é a desorganização dos plastídios seguida de oxidação e coagulação mais ou menos pronunciada do protoplasma.

Os peritécios do fungo, como acima dissemos, se formam sôbre o subículo. São desde os seus primórdios, globosos. Diferindo das demais

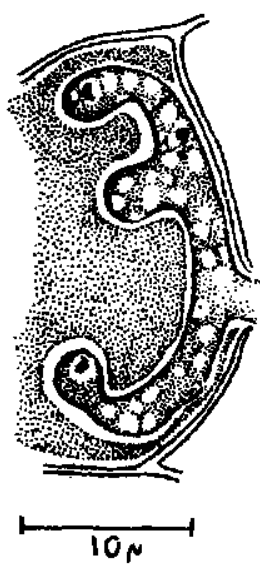

Fig. 2 espécies do gênero, as suas paredes, ao invés de serem formadas por uma espécie de mosaico de células, são um trançado ou enovelado de filamentos hifais (Est. I). A parede dos peritécios é espêssa, fusca, e em cortes se mostra formada de elementos juxtapostos, paralelos, septados, uninucleados, (Fig. I do texto). Coroando o tôpo dos peritécios encontra-se úm ostíolo típico. É elevado ou um tanto cônico mesmo. Circundam-no 3 ou 4 setas, fuscas, lisas, septadas ou não, divaricadas, que alcançam $50 \mu$ de altura (Est. I). Nos peritécios jovens, as setas não são patentes. $\bigcirc$ tipo de insərção dos peritécios às hifas do subículo, se acha ilustrado na figura 1 do texto. Por ela se vê que os peritécios apenas se prendem aos elementos do subículo. Não existem outras quaisquer estruturas à base peritecial.

Os ascos são numerosos, desprovidos de paráfises (Fig. 3 do texto), curtíssimo-pedicelados, clavulados, octosporos, medindo 50-60 x 8-9 $\mu$. Para o tamanho dos peritécios maduros, cujas medidas oscilam entre 120-160 $\mu$, verifica-se que os ascos são relativamente pequenos. Os ascosporos são bicelulares, dísticos ou subdísticos, hialinos, gutulados, com a célula superior um pouco mais desenvolvida que a inferior (Fig. 4 do texto), constritos no septo e um bocado dilatados acima e abaixo do dito septo. Medem 14-20 × 3,5-4 $\mu$, trazendo a parede delicada, hialina e lisa. Ao germinar, os esporos absorvem água. Entumecem (Fig. 5 do texto) e emitem, polarmente, um ou dois tubos germinativos hialinos, delicados, de extremidades obtusas.

Quando material fresco, colhido no campo e trazido para o laboratório é examinado sob a lupa, verifica-se que muitos peritécios são conchóides (Est. I). A metade superior da parede peritecial se afunda. Os peritécios mais parecem pequeníssimas cuias avermelhadas. Posto o material em cômara úmida, as hifas

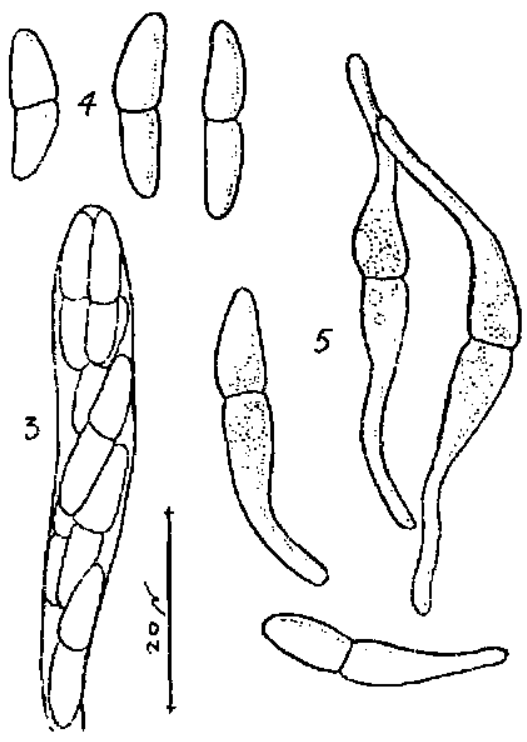

Figs. is, 4 e: se tornam túrgidas e a parede volta à posição normal primitiva. Êsse fenômeno ocorre a outras espécies de Nectria, não constituindo, portanto, nenhuma novidade. $O$ que é interessante na espécis, é a textura da parede peritecial, e seu parasitismo 
apenas às fôlhas das plantas assinaladas anteriormente. Neste particular, a espécie é notável. Além disso, não produz estado conidiano algum. Êste deveria ser um Fusarium ou mesmo Verticillium. A-pesar-de havermos trabalhado com abundante material colhido em Mogí-Mirim, não nos foi possível obter culturas do fungo. A êste respeito, a espécie também se comporta diferentemente das demais pertencentes ao gênero Nectria, as quais, como se sabe, são fàcilmente cultiváveis em meios artificiais. As nossas culturas não passaram além do estado representado na figura 5 do texto.

Citològicamente, só pudemos acertar com exatidão, o carater uninucleado das células do micélio vegetativo, e das células componentes dà parede dos peritécios. A formação das hifas ascógenas, o aparecimento subsequente dos ascos, o mecanismo da formação dos ascosporos, tudo isso nos escapou à análise, em virtude de pequenez dos núcleos. Parte de uma nossa coleta, enviamo-la ao Dr. Julian H. Miller, de Geórgia, USA., para identificação. Im cartã cue nos escreveu julgou que o fungo deveria ser parasítico a algum outro atacando as fôlhas de Jirythroxylum. En cutras palavras, o organismo soria apenas secundário. Inlelizmente, sem culturas puras, não pudemos levar avante nosso plano de executar experî̀ncias de inoculação artificial com Nectria erythroaylifolia. Mas certas observações laterais, parecem nos conduzir a caminho oposto ao do nosso consultado. O estudo dàs lầrninas em série, cortadas ao micrótomo rotativo, coloridas à hematoxilna, nos autoriza afirmar çue há continuidade perfeita das hifas encontradas nos teciqos, desde os haustórics até o exterior, no subículo e peritécios. Al m disso, a espécie ocorre zôbre dois membros do gênero liryihroxylum, isto é, fi. sulerosum St. Hil., e F. campestre St. Hil. in venhunia delas observamos quaisquer traços ou resquícios de hifas outras que não as de Neclria erylihroxylifolive. A-de-mais, nas espécies de fungos parasíticos a outros fungos, o exame histológico sempre revela hilas envolventes do parasita sôbre envolvidas do parasitado. E isso năo ocorre em nenhum dos materiais coletados desde Mogí-Mirim até Belo Horizonte ou Lagoa Santa.

Assim sendo, consideramos a espécie como boa $\in$ nova.

\section{NICTRII ERYTIIROIYTIFOLIE N. SP.}

Maculis epiphyllis, raro hyrophyllis, orbiculatis, sparsis vel coalescentibus, fuscis. Peritheciis globosis, siccitate conchoideis, polyascis, 120-160 $\mu$ diam., superficialibus, ostiolo conico instructis, ex hyphis teretibus, septatis, uninucleatis, fuscis textis, in mycelio arachnoideo, denso, hyalino, persistente, scepius epiphyllo nidulantibus. Setae 3-4, rectae, plerumque septatae, simplices, fuscae, divaricatae, glabrae, usque $50 \mu$ longae. Ascis clavulatis, 50-60 × 8-9 $\mu$, breve pedicellatis, octosporis, aparaphysatis. Sporidia

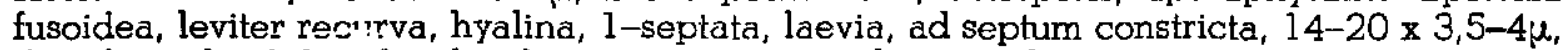
disticha vel subdisticha, loculo superiore parum latiore. Status conidicus deest. Hyphis intercellularibusque hyalinis, septatis, 4-4,5 diam., per stomata atque epidermidem fissam in fasciculis emergentibus, haustoribus ramosis, polynucleatis, indistincte septatis praeditis.

In foliis vivis Erythroxyli suberosı St. Hil. (typus), leg. Glauco Pinto Viégas, prof. Henrique de Melo Barreto et H. P. Krug, in dumetibus prope Lagoa Santa, Prov. Minas Gerais, Brasiliae, 8 April., 1936. Typus sub numero 1919, in herbario I.A., Campinas, Prov. S. Pauli, Brasiliae. 


\section{PUCCINIA ERYTHROXYLI N. SP.}

Não foram inúteis os nossos esforços em procurar um suposto parasita de Erythroxylum suberosum St. Hil., nos arredores de Mogí-Mirim, a-fim-de poder explicar a hipótese de Miller (pag. 52), pois nos foi dado - prazer de descobrir uma espécie de Puccinia aparentemente nova para a ciência.

No dia 14 de outubro de 1941, em companhia de Glauco Pinto Viégas, rumamos para os cerrados da vizinha cidade de Mogí-Mirim, com o fito de procurar novos parasitas da Erythroxylacex. Examinando, naquela época do ano, fôlhas novass da planta, a atenção de Glauco Pinto Viégas foi despertada por algumas fôlhas recem-brotadas exibindo concavidades pronunciadas de belíssimo amarelo côr de gema. As concavidades eram grandes, variando de 1 a $2 \mathrm{~cm}$ de diâmetro. Examinadas à lente de bolso de 14 diâmetros, não revelaram nada de particular nem na face côncava amarela, nem na oposta convexa e esverdeada. Trazido o material para laboratório e cortado em estado fresco, com navalha comum, não nos pudemos certificar com segurança de que fungo se tratava. Gotas numerosas de material oleoso e amarelo impediam exame minucioso, pelo que resolvemos secar parte do material dos soros para cortá-lo. Os resultados toram ótimos. Obtivemos belíssimos cor-

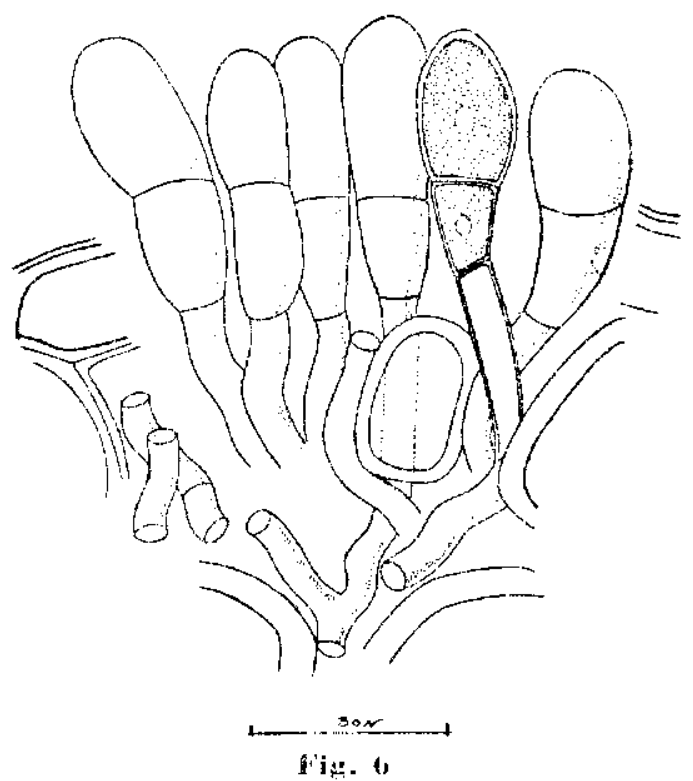
tes que vieram confirmar a nossa suposição de que se tratava de uma ferrugem.

Os teliosporos são hipófilos, primeiro subepidérmicos, depois irrompentes (Fig. 6 do texto), semi-imersos, em orupos, oblongo-clavulados, lisos, hialinos, 38.42 x.10 $15 \mu$, não, ou levemente constritos no septo, de paredes de $2 \mu$ de espessura, longo pedicelados de $4-6 \mu$ de diâmetro, concolor. A célula distàl dos teliosporos tem a extremidade obtusíssima. Micélio hialino, septado, intercelular, de 4-6 de diâmetro. Picnios ausentes.

A espécie parece ser, pelos seus caracteres, uma lepto-Puccinia, e até o presente, que saibamos, não foi descrita.

Sôbre fôlhas de Erythroxylum suberosum St. Hil., leg. G. P. Viégas e A. P. Viégas, cerrado perto da cidade de Mogí-Mirim, Estado de São Paulo, 12 de outubro de 1941. Material tipo sob n. ${ }^{\circ} 3879$ no herbário do I. A., Campinas, Estado de São Paulo. 


\section{PUCCINIA LRYTIROYYLI N. SP.}

Teliosoris magnis, conchoideis, flavidis, $1-2 \mathrm{~cm}$ diam., glabris. Teliosporis epidermide tectis, dein erumpentibus, semi-immersis, hvalinis, laevibus, longe pedicellatis, $38-42 \mathrm{x}$ 10-15i, ad septum leviter constrictis, cellula superiore apicem versus obtusissima, tunica 2u crassa. Mycelium intercellulere, 4-6ie diam., septatum. Pycnia desunt.

In folis vivis Erythroxyli "uberosi St. Hil., leg. G. P. Viégas et A. P. Viégas, ir dumelis prope Mog'-Mirim, Prov. St. Pauli, Brasiliae, 12 Oct., 1941. Typus sub r. 3879 in herbario I. A., Campinas, Prov. St. Pauli, Brasiliae.

\section{IIETIOLA JAVIGERA SPEG.}

Um dos gêneros mais difíceis de fungos, especialmente aquí no Brasil, vem a ser o cênero Aleliola. Palta-nos uma monografia completa e mais detalhada das espécies até agora coletadas. Raramente conseguimos identificar a contento crtos materiais herborizados. Adotamos como princípio não tentar dascificá-ios a menos que a planta em que ccorrarn seja identificada palo menos até gênero. A espécie seguinte é fregùente nos cerrados de Săo Paulo. Foi descrita por Spegazzini (2). Produz colônias negro-velutinas, anfígenas, de 1/2-1 cm de diânetro, fàcilmente destacáveis, esparsas ou confluentes (Esst. II, fig. a). Micólio hifopodiado, ramificado, sinuoso, septado, de 7-8u de diametro, levemente incrustado, fusco (Est. Il, fios. b, c). Hifopódios clavulados, ou cilíndrico-clavulados, fuscos, alternos, $12-16 \times 11$ s. providos de uma célula basal de 6-8; de alto. Setas micelianas, fuscas, septadas, nume. rosas, flexuosas, recurvas on sinuosas, de 7 . 8 de diâmetro, atingindo 250300 de comprimento, terminando em ponta obtusa e de côr, por vêzes, nais clara. peritécios (cleistotécios) globosos, negros, ástomos, $250-900 \%$ de diametro, quardo secos denimidos ou conchóides (Est. II, fio. b), rodeados de setas idênticas às micelianas. Ascos bisporos, ¿̀s vêzes com três esporos, de paredes que se gelatinizam logo, globosoovóideis, curtíssimo-pedicelados ou mesmo sésseis, 50-60 x 28-30\% (Est. II, fig. d). Áscosporos fuscos, com quatro sertos transversais, constritos nestes, retos, de paredes lisas, 3842 x 10-16u (Est. II, fig. e).

Sôbre fôlhas de Jithrou sp., leg. A. P. Viégas, cerrado, perto de MíogíMirim, Est. de S. Paulo, 30 de abril de 1941.

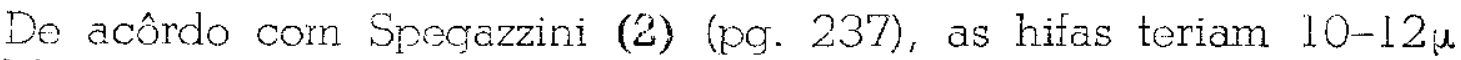
de diametro, dimensc̈es essas que não estão de perfeito acôrdo com as do nosso material.

\section{APIOSPIIARIA (EUARANITTCA (SPEG.) VON HOEHNEL}

Uma das espécies mais comuns em ipês em cerrado vem a ser esta, primeiramente descrita por Spegazzini (3), em 1883. Spegazzini pô-la no gênero Aunkiella, gênero êsse de sua autoria (3) (4). Rehm (5) seguiu Spegazzini, ao classificar material proveniente do Paraguai. Na revisão geral dos Dothideales, Theissen e Sydow (6), depois de emendar os caracteres do gênero Munkiella, fundamentando-se em trabalho anterion de von Hoehnel que não tivemos a oportunidade de ver ainda, 
(Fragmente zur Mykologie VIII, N. ${ }^{\circ}$ 392), confirmaram a transferência de Munkiella guaranitica Speg. para o gênero Apiosphoria. Assim, ○ organismo ficou sendo conhecido pelo nome de Apiosphoria guaranitica (Speg.) von Hoehnel (6) (7) e não Apiosphoria guaranitica (Speg.) Sydow, como escreveu Bitancourt (10). Ao trabalhar com fungos da Venezuela, Sydow (9) apresentou descrição detalhada de Apiosphoria guaranitica (Speg.) von Hoehnel, concluindo que "Apiosphoria steht den Gattungen Phyllachora, Physalosporina und Polystigma sehr nahe", diferenciando-se "durch die sehr ungleich septierten, mit papillenfoermiger Unterzelie versehenen Sporen". Nesse trabalho ainda, Sydow descreve o estado imperfeito de Apiosphxiraguaranitica (Speg.) von Hoehnel, ao qual dá o nome de Rhodosticta. Esse mesmo estado imperfeito fôra descrito e ilustrado por Rangel (8), como Oswaldina icarahyensici. Sydow (11) não reconheceu Oswaldina icarahyen siv Rangel, dando a entender com isso que Rhodosticla tem prioridade sôbre Oswaldina.

$O$ fungo forma crostas pardo-amareladas, depois pardas, que se tornam mais escuras ao envelhecer. Quando passadas, são quase negras ou negras mesmo (8). As crostas são salientes, de bordos ora nítidos, ora obscuros ou indefinidos. Podem nascer isoladas ou fundir lateralmente, às vêzes recobrindo quase tôda superfície foliar (Fig. 7 do texto). As crostas, que não

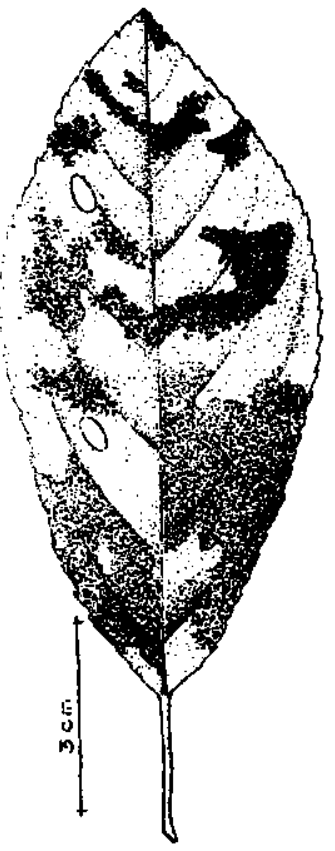

Fig. 7 passam de um estroma, se localizam entre a epiderme e o təcido em paliçada, aumentando assim consideràvelmente a espessura do limbo. Comparem-se as figuras $\mathbf{a}$ - normal, e $\mathbf{b}$ - atacada (Est. III). Formado o estroma, não demoram a aparecer os picnídios do estado imperfeito. $O$ modo pelo qual estas estruturas se formam, não pudemos determinar com certeza. Quando maduros, vão desde a epiderme superior até quase a epiderme inferior (Est. III, fig. b). Medem 100-200 x 160 320 . Abrem-se por um poro, rodeado por células que se tornam escuras por oxidação. O poro é estreito, e por êle sai a massa de esporos sob a forma de cirro amarelo. As paredes dos picnídios são nítidas, delicadas, não passando de 8-10 $\mu$ de espessura. Na sua face interna, os picnídios se recobrem de conidióforos. Os conidióforos são hialinos, ramificados (8) subverticiladamente. Cada ramo principal traz 3-4 ramos secundários. Os ramos secundários se separam do principal por um septo. São dilatados na base afilando-se para a extremidade distal. A história nuclear dos conidióforos é difícil de ser estudada em cortes transversais de $10 \mu$ de espessura de material fixado, cortado ao micrótomo e colorido à hematoxilina. Todavia, queremos crer que cada ramo secundário, dilatado na base, é portador de um núcleo. Êste, pela divisão, dá dois núcleos, dos quaes um fica na própria célula (que então funciona como célula mãe) e o outro passa ao esporo. Os esporos são filiformes, hialinos e lisos, de extremidades obtusas. São recurvos 


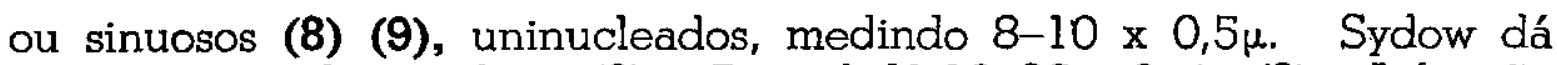

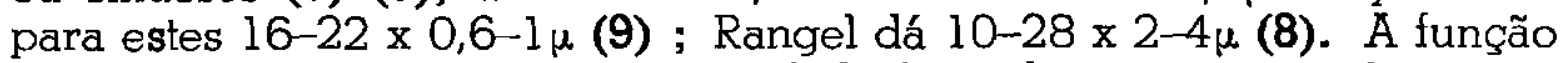
dêstes esporos, ao que nos parece, é de fecundação, muito embora não pudéssemos demonstrar experimentalmente êste fato.

Das profundezas do estroma, erguem-se, em direção à superfície (Est. IV, figs. a, b e Est. V, fig. a), uma ou mais hifas, septadas, de grande diâmetro (6-8 $\mu$ nas preparações coloridas pela hematoxilina), sinuosas ou espiraladas. Essas hifas se enrolam em tôrno de duas células grandes centrais (na Est. IV, fig. a, só se vê uma, em $\mathbf{x}$ ), que aparentemente fucionam como ascogônio e tricógino, respectivamente. Fenômenos de redução não observamos em nenhuma destas duas células. Na sua morfologia não diferem das que foram descritas para Polystigma rubrum (16). São multinucleadas e septadas (Est. VI, fig. b), e de início tais hifas se elevam verticalmente. Depois que se opera a fecundação (?), desaparecem. A célula que funcionou como ascogônio ramifica-se ràpidamente (Est. V, fig. b). As hifas dela derivadas são também de grande diâmetro, e de protoplasma denso. Ocupam posição basal, formando um núcleo, enquanto outras hifas se enovelam em tôrno dêste núcleo ou massa de células (Est. VI, fig. a) de forma lenticular. $O$ eixo dêste conjunto passa pelo ostíolo. Em outras palavras, as hifas do primórdio do bojo do peritécio se dispõem agora quase paralelas ao plano da superfície do estroma. Sofreram, pois, uma torção de 90 graus. A camada mais exterior destas hifas do bojo, formará a parede peritecial. Na base do bojo, a parede se afunda um bocado, penetrando no tecido em paliçada subjacente (Est. VI, fig. c). Na porção oposta, as células se erguem e irão constituir o pescoço do peritécio. Já por essa época, as hifas do núcleo se transformaram em verdadeiras hifas ascógenas. As hifas ascógenas crescem verticalmente na parte central do núcleo, e inclinadamente aos lados, dando origem aos ascos. $\grave{A}$ maturidade, o pescoço peritecial mede 100-160: de comprimento e 40-50 $\mu$ de diâmetro. O bojo mede 500-600 $\mu$ de diâmetro e cêrca de $200 \mu$ de alto. A parede alcança cêrca de $20 \mu$ de espessura. Os ascos, à maturidade, são clavulado-cilíndricos, curto-pedicelados, octosporos, medindo 75-80 × 10-12 $\mu$. Paráfises não se formam, mas perífises são abundantes ao derredor do ostíolo. Ascosporos, à maturidade, são hialinos, lisos, providos de um apêndice basal. Medem os ascosporos 12-14 x 9-10 $\mu$; o apêndice, $4-5 \times 2-3 \mu$. O fungo é de larga distribuição geográfica. Ocorre desde a Venezuela até o Paraguai. Sôbre fôlhas de Tecoma araliaceo DC., (8), Tecoma longiflora Griseb. (8), Tecoma sp. (5) (9) (10) aquí no BrasiI e no Paraguai. Sôbre Tabebuia chrysantha Nichols. (9), na Venezuela.

No que toca à posição sistemática do organismo, quer nos parecer que êle ficará bem colocado, se incluido na família Phyllachoracex, tal como Miller (15) a define. Neste ponto, estamos com Sydow que a estudou minuciosamente (9). Mas, por outro lado, em Phyllachoraceve, que saibamos, não ocorre formação de tricógino. Pelo menos, nas pesquisas de Orton (14), não ficou explicado se o enovelar das hifas formadoras do peritécio é semelhante ao descrito para Polystigma rubrum 
(16). O que nos parece mais razoável seria considerar a família Phyllachoracere como distinta, por liaremos, assim procedendo, os pontos de vista de vários autores, inclusive - de Clemens e Shear (12), que talvez possa parecer estranho à primeira vista.

\section{SCHNEEPIA ARECHAVALETA SPEG.}

Corpos de frutificação circulares, negros, esparsos (Fig. 8 do texto), epífilos, de 1,5-2,5 $\mathrm{mm}$ de diâmetro, radialmente sulcados, de superfície lisa (Fig. 9 do texto), trazendo uma parte estéril central. Peritécios alongados no sentido radial, às vêzes em $\mathbf{V}$, de $1 \mathrm{~mm}$ de comprimento na média, 200 $\mu$ de diâmetro e 160-170 $\mu$ de alto. Paredes periteciais, negras, carbonáceas, de 35-40 $\mu$ de espessura (Fig. 10 do texto). Ascos

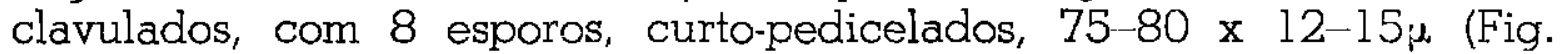
11 do texto). Paráfises numerosas, cilíndricas, na extremidade clavuladas e fuscas, cêrca de 20-25 $\mu$ mais longas do que os ascos. Ascosporos bicelulares, fuscos, lisos, com a célula distal globosa e a basal um tanto alongada ou subcilíndrica, 16-18 x 7-8: (Fig. 12 do texto).

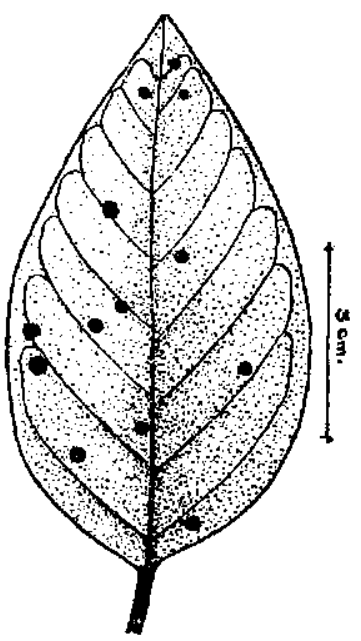

Fig. 8

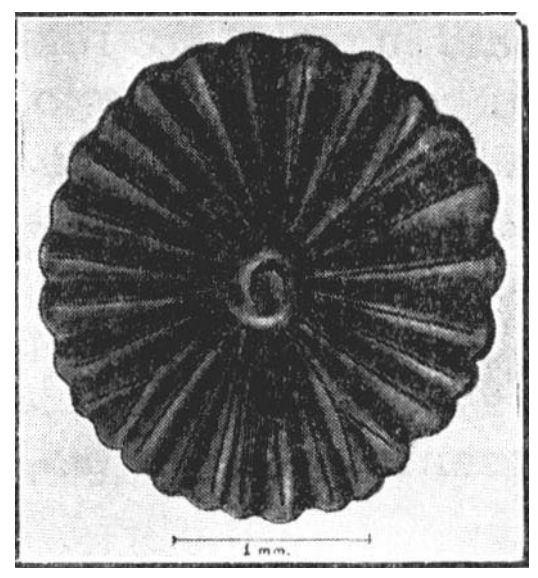

Fig. 9

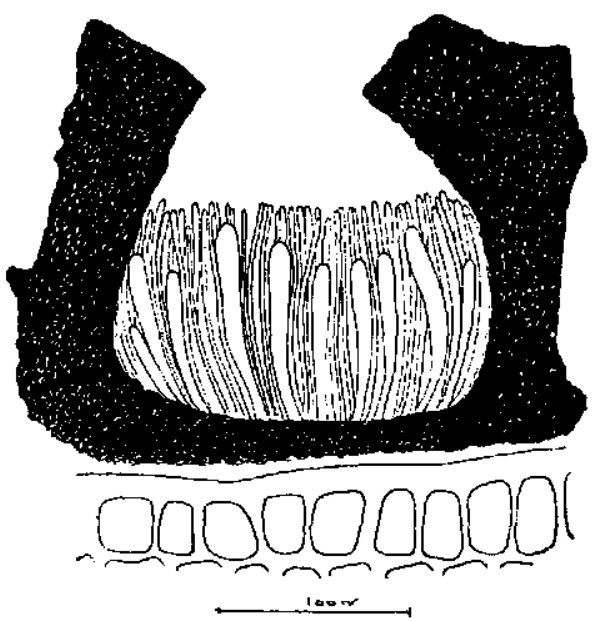

Fig. 10

Sôbre fôlhas de Styrax sp., leg. A. P. Viégas e G. P. Viégas, cerrado, Mogí-Mirim, Estado de São Paulo, 12 de outubro de 1941.

A espécie (tipo de Scheepia arechavaleto Speg.) foi coletada por J. Arechavaleta, num cerrado perto de Itabira do Campo, Rio das Velhas, em setembro de 1887. O nome da localidade e o nome do rio estão a indicar o Estado de Minas Gerais, e não o Estado de São Paulo, como dão Theissen e Sydow (6). O material tipo foi examinado e descrito por Spegazzini (17). A diagnose da espécie apareceu à página 1098 do "Sylloge fungorum" de Saccardo (18), e belas ilustraç̃̃es podem ser vistas na primeira edição do Engler e Prantl (19), à página 274.

O gênero Scheepia, erigido por Spegazzini, é mais recente do que Parmularia Lev. Todavia, seguimos a autoridade de dois grandes mico- 
logistas: Theissen e Sydow (6) (7). Se estes assim procederam é porque deveria haver uma razão bastante forte, decisiva. Se quisermos saber qual seja, basta lançarmos mão do "Sylloge fungorum" (13),

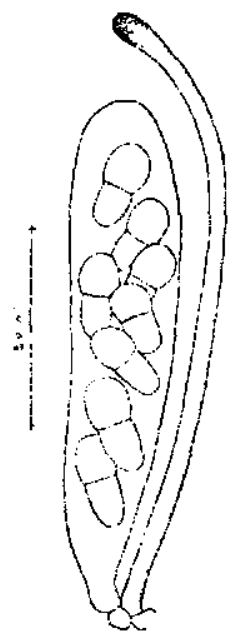

Iix. II onde, à página 404, se lê: Schneepia Speg. -- Parmularia Lév. quia imaturum.

Schneepia, de acôrdo com Theissen e Sydow (7) (13) faz parte da família Polystomellaceo que se carateriza (13), por trazerem (os seus representantes) um "scutellum", (isto é, um escudozinho ao qual aplicamos o têrmo estroma neste trabalho) "radiatim constructum" (a saber, formado de hifas que se dispõem no sentido radial) ; "mycelium filiforme vel nullum" (e neste caso, o gênero Schneepia viria a cair no grupo compreendido pelo adjetivo "nullum"), "perithecia adnata" (isto é, adnatos ou firmemente colados; neste caso, à superfície foliar), "perithecia superficialia, hypostromate adnata" (com os corpos de frutificação superficiais, mas presos por meio de um hipostroma ou estroma basal).

Se no parágrafo anterior ros volvemos a detalhes estritamente taxonômicos, como que traciuzindo os dizeres da chave que aparece em Saccardo (13), foi apenas para pôr em relêvo um ponto que não pudemos investigar até agora, no referente a Schneepia arychavaletoe Speg., ou seja o modo pelo qual se fixam às fôlhas os corpos de frutificação do fungo. Um tal estudo, para ser completo estaria a exigir exame de lâminas contendo cortes de material prèviamente tixado e incluido em parafina. Não pudemos fazer isso até o presente. Também, seria de grande interêsse estudar, paralelamente

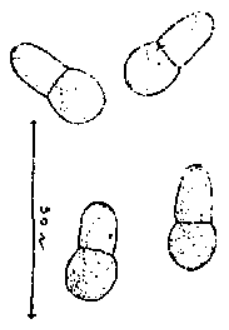

Fïg. 12 a uma tal investigação, o desenvolvimento dos estromas do organismo em questão.

\section{TRICHODOCHIU.H DISSEAINATUM SYDOW}

Micélio aéreo hipótilo, septado, de $4-5 \mu$ de diâmetro, cilíndrico, liso, com anastomoses freqùentes, por vêzes reunido em feixes indis-

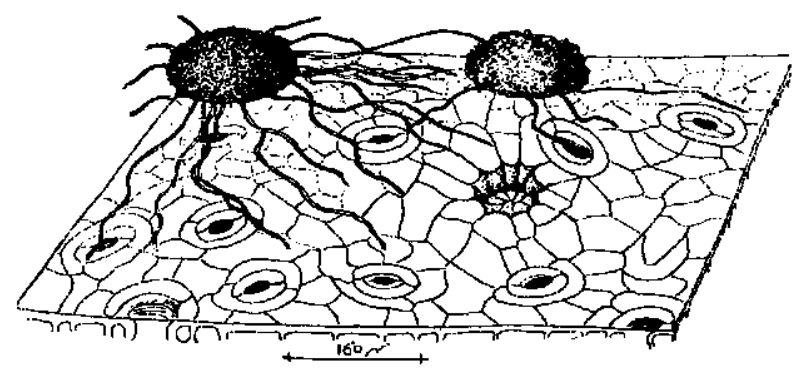

Fig. 13 tintos que unem, embora afastadamente, os corpos de frutificação entre si (Fig. 13 do texto).

Esporodóquios compactos, exteriormente pulvinados, negros, e que em cortes transversais (verticais) (Fig. 14 do texto) se mostram constituidos de um pé, largo de $35-40 \mu$, o qual se fixa à cavidade glandular e duma porção pulvinada, aérea, de 150-160 $\mu$ de alto, formada de hifas radiais de $4-5 \mu$ de diâmetro, septadas, fuscas, que produzem conídias em 
cadeias nas suas extremidades distais (Fig. 14 do texto). Por vêzes, as hifas do esporodóquio continuam seu crescimento e dão origem ao micélio aéreo acima referido. Conídias fusco-negras, ásperas, bicelulares, oblongo-elípticas, constritas no septo, 15-18 x 7-10 (Fig. 15 do texto), por vêzes, com uma estria longitudinal de côr mais clara.

fungo foi coletado sôbre fôlhas de Rapanea so., por A. P. Viégas e professor Henrique de Melo Barreto, nas proximidades de Cachoeira do Campo, Estado de Minas Gerais, em 28 de junio de 1941.

Sydow (20) diz que os esporodóquios (e digamos de passagem que o fungo ao que nos parece não havia sido coletado aquí no Brasil e sim em Costa Rica) nas-

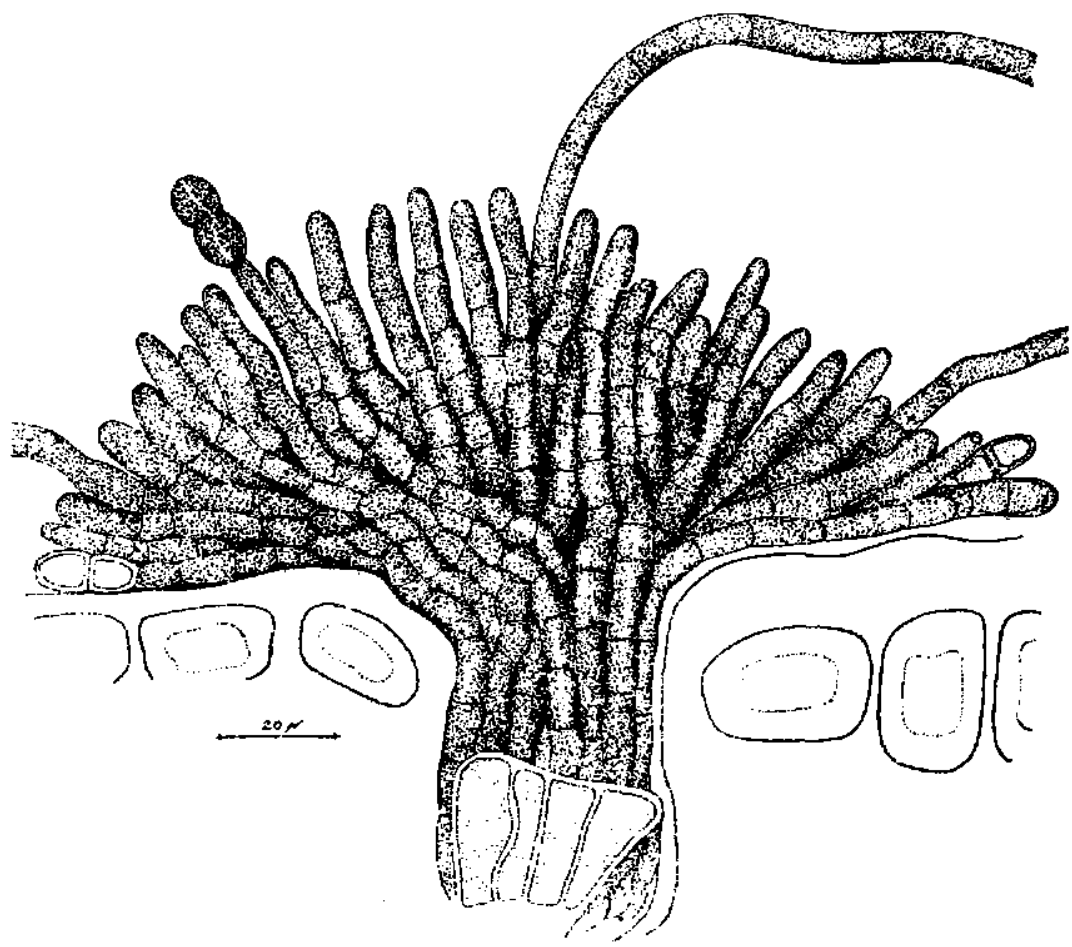

Nig. 11 cem a partir dos estômatos ou estão presoś a essas estruturas (stomatibus aftixa), o ciue nos parece inexato. Pelo menos, em nosso material, os pedicelos dos esporodóquios se fixam às glândulas foliares, muito mais amplas que as cavidades estomatais. A abertura estomatal neste material de Rapanca com que trabalhamos, é muito pequena para per-

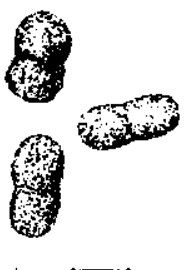

fip. lip mitir a fixação dos esporodóquios. Sydow (20) quando se refere a um hipostroma de 25-30:1 de diâmetro, com tôda a certeza confundiu estômatos com glândulas, porquanto um hipostroma deve ser uma estrutura larga, bastante visível. A-de-mais, se êsse hipostroma se desenvolvesse num estômato, êste se deformaria e com tôda a certeza deveria o fungo ocasionar algum dano à planta. Se fazemos estas especulações sôbre uma coisa que não vimos - o material costaricense - e neste ponto confessamos a nossa imprudência, por outro lado não temos outra coisa em mira senão demonstrar a inteira identidade entre o que foi tão bem descrito por Sydow (20) e o que toi por nós encontrado aquí tão distante. Outro pormenor a se notar é o seguinte: no material costaricense, Sydow (20) descreve setas longas, simples "plus minusve curvatis". Repete essas mesmas palavras no texto em alemão. No material mineiro não há setas e sim crescimento vegetativo de conidióforos. 


\section{DIPLOCHORELLA INDAIÁ N. SP.}

Uma das plantas mais comuns do cerrado paulista vem a ser a palmeira anã, indaiá. Um dos fungos interessantes que ocorre nas fôlhas desta planta vem a ser o que agora descrevemos como nova espécie.

As lesões são anfígenas, isto é, são encontradas em ambas as faces das fôlhas. Quando isoladas, elípticas, pardas, $3-5 \times 2-2,5 \mathrm{~mm}$, de margem colorida mais intensamente. São as manchas ainda circundadas por uma zona de transição ou halo amarelado. Freqùentemente, as lesões coalescem (Est. VII), formando áreas necróticas irregulares, nítidas, de vários centímetros de comprimento, mas nas quais se percebem, embora apagadamente, às vêzes, as lesões iniciais ou primárias. Quando idosas, adquirem coloração ou reflexos prateados na parte central. Já por êsse tempo, ou pouco antes, no centro das manchas a epiderme se rasga em forma de alçapão, deixando ver, de sob a tampa assim formada (Est. VIII, a), os corpos de frutificação do fungo. O micélio invade os espaços intercelulares (Est. VIII, b). Sob a epiderme êle forma um estroma (Est. VIII, c), negro-fusco, cujas células se dispõem de modo irregular (estrutura intricata). Nestes estromas, é que aparecem os lóculos. Com o crescer dêstes, a epiderme, já rompida, se destaca. No fundo da cratera rasa formada, percebem-se perfeitamente os lóculos, que se dispõem com frequência ao longo das margens da cratera. Os lóculos variam de globosos e piriformes, lisos. Trazem urn papila mais ou menos nítida que se abre por um poro (Est. VIII, fig. d). Os estromas ascígeros são uniloculares. Medem 45-50 x 70-80p. Os sacos são fasciculados, curto-pedicelados, obclavulados, trazendo a parte superior espêssa, refringente. Medem 50 60 x 10-12 $\mu$, são aparafisados, octosporos. Ascosporos (Est. VIII, fig. e) hialinos, 1-septados, lisos, 10-14 x 2-2.5u, clavulados e ligeiramente recurvos.

Sôbre fôlhas de Cocus petrea Mart. (indaiá), leg. A. P. Viégas, Campo Grande, Est. de São Paulo, 12 de dezembro de 1940.

$\mathrm{Na}$ literatura a nosso dispor, não conseguimos encontrar nenhuma espécie do gênero com os caracteres da espécie acima, pelo que a tomamos como nova. Tipo sob número 3574, no herbário do I. A., Campinas, Est. de São Paulo.

\section{DIPTOCHORELLA IND.1YÁ N. SP.}

Maculis numerosis, ellipticis, amphigenis, fuscis, sparsis, 3-5 × 2-2,5 mm., dein coalescentibus, irregularibus, variis $\mathrm{cm}$ longitudinis, atro-brunneo-marginatis, halo flavida

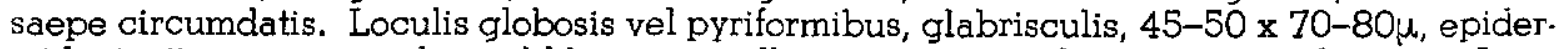
mide tectis, postea nudis, subliberis, papillatis, poro apicali plerumque donatis. Ascis fasciculatis, octosporis, breve pedicellatis, obclavatis, apice crassissimis, hyalinis praeditis, 50-60 x 10-12 $\mu$, aparaphysatis. Sporidiis clavulatis, hyalinis, laevibus, 1 -septatis, $10-14 \times$ $2-2,5 \mu$.

In foliis vivis Coci pelrexe Mart. (indayá), leg. A. P. Viégas, Campo Grande, Campinas, Prov. St. Pauli, Brasiliae, Amer. Austr., 12 Dec., 1940. Typus sub numero 3574, in herbari. I. A., Campinas, Prov. St. Pauli, Brasiliae. 


\section{SEPTOIDIUA DIDYMOPANACIS N. SP.}

Lesões anfígenas, isoladas, circulares ou subcirculares, nitidíssimas na página inferior dos folíolos (Est. IX), e de côr chocolate, feltrosas, de 5-10 mm de diâmetro, na página superior primeiramente amareladas depois pardas.

Hifas intercelulares, cilíndricas, de $3-5 \times 4 \mu$ de diâmetro, ramificadas, septadas, enviando haustórios para o interior das células, depois reunindo-se em feixes compactos que ganham o exterior através das aberturas estomatais (Est. X, fig, a, b), onde se expandem de modo irregular formando emaranhacios fuscos, elusos. Conidióforos não diferentes do micélio interno, rämificados, septados, fuscos, anastomosandose aquí e alí, e alcançando 200-300; de altura, exibindo diâmetros variáveis que vão de 4 a $6 u$, subtorulosos, gutulados, constritos ou não nos septos transversais. Conídias septadas, oblongo-cilíndricas, fuscas, de paredes duplas, extremidades obtusas, 20-50 x 7-8: (Est. X, fig. c), e base troncônica portadora de uma escara bem níticia, não exibindo constriçöes na parede lisa.

Sôbre folíolos de Didymopanar sp., leg. A. P. Viegas, Campo Grande, Camoinas, Estado de São Paulo, 12 de dezembro de 1940.

O orgarismo invadindo os tecidos foliares causa uma hipertrofia das células componentes do parêriquima lacunoso (Est. X, fig. a).

O estado perteito associado a Seploidium deverá ser procurado ern Paiodiopicir. A respeito dêste e de outros gêneros afins, consultar Arnaud (21).

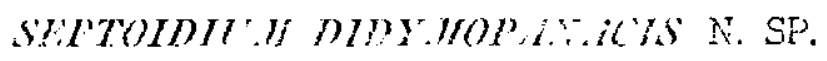

Maculis amphigenis, in epiphyllo fusco-brunneis, glabris, in hypophyllo, castaneis, flccosis, $5-10 \mathrm{~mm}$ diam., rotundatis, sparsis.

Hyphis intramat:icalibus, ramosis, septatis, fuscis, 3,5-4u. diam., haustoribus praeditis. Hyphis extramatricalibus (conidiophoris), fuscis, septatis, laevibus, guttulatis, subtorulosis, anastomosantibus, : 4-6 $\mu$ diam., repentibus.

Conidiis oblongo-cylindraceis vel clavatis, fuscis, septatis, non ad septa constrictis,

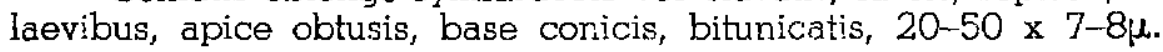

In foliis vivis Didymopanacis sp., leg. A. P. Viégas, Campo Grande, Prov. St. Pauli, Brasiliae, Amer. Austr., 12 Dec., 1940. Typus in herbario I. A., Campinas, sub numero 3571.

\section{LITERATURA CITADA}

1. Warming, Eugênio. Em Lagoa Santa, pgs. 1-282, fig. 1-43. Imprensa Oficial do Estado de Minas Gerais. Belo Horizonte, 1908. (Versão portuguesa de A. Loefgren).

2. Spegazzini, C. Mycetes argentinenses. Anales del Museo Nac. de Buenos Ayres 19: 257-458. 1909.

3. Spegazzini, C. Fungi guaranitici I. (N. ${ }^{\circ}$ 283), 1883. Citado por Theissen e Sydow (6). (Não conseguimos ainda o original).

4. Saccardo, P. A. Em Sylloge fungorum 9: 1-1141. 1891. (pg. 1034). 
5. Rehm, H. Beitraege zur Pilzflora von Suedamerika III. Hedwigia 36: 366-380. 1897.

6. Theissen, F. e H. Sydow. Die Dothideales. Annales Mycologici 13: 149-746. 1915.

7. Theissen, F. e H. Sydow. Synoptische Tafeln. Annales Mycologici 15: 389-491. 1917.

8. Rangel, Eugênio. Nota sôbre dois fungos. Arquivos da Escola Superior de Agricultura e Medicina Veterinária (Niterbi). 5: 35-39, est. 3-5. 1921.

9. Sydow, H. Fungi venezuelani. Annales Mycologici 28: 29-224. 1930.

10. Bitancourt, A. A. Relação das doenças e fungos parasitas observados na Seç̧ão de Fitopatologia durante os anos de 1931 e 1932. Arquivos do Instituto Biológico 5: 185-196. 1934.

11. Sydow, H. Fungi venezuelani. Additamentum. Annales Mycologici 33: 85-100. 1935.

12. Clemens, F. E. e C. I. Shear. Em Genera of Fungi, pgs. 1-496, pl. 1-58, H. W. Wilson Co., New York, 1931.

13. Saccardo, P. A. Em Sylloge fungorum 24: 1-703. 1926.

14. Orton, C. R. Studies in the morphology of the ascomycetes I. The stroma and compound fructification of the Dothideaceae and other groups. Mycologia 16: 49-95, fig. 1-2, pr. 7-9. 1924.

15. Miller, Julian H. The ascomycetes of Georgia. Plant Disease Reporter Supplement 131: 31-93. 1941.

16. Gaumann, E. A. e C. W. Dodge. Em Comparative morphology of fungi, pgs. 1-701, ill., 1." ed., Mc Graw Hill Book Co., 1928. (Ver pg. 229-23i).

17. Spegazzini, C. Fungi puiggariani, pugillus I, pg. 1-244. 1889. (Sep. Bol. Acad. Siencias de Cordoba 11: 381 e seg.).

18. Saccardo, P. A. $F m$ Sylloge fungorum 9: 1-1141. 1891.

19. Lindau, C. Hysterineae. Em Engler e Prantl, Die naturlichen Pflanzenfamilien, Teil I, Abt. pg. 274, fig. 198. 1897.

20. Sydow, H. Fungi in itinere costaricense collecti. Annales Mycologici 25: 1-160. 1927.

21. Arnaud, G. Étude sur les champignons parasites. Annales des Épiphyties 7: 1-115. pr. 1-10. 1921. 
Est. I

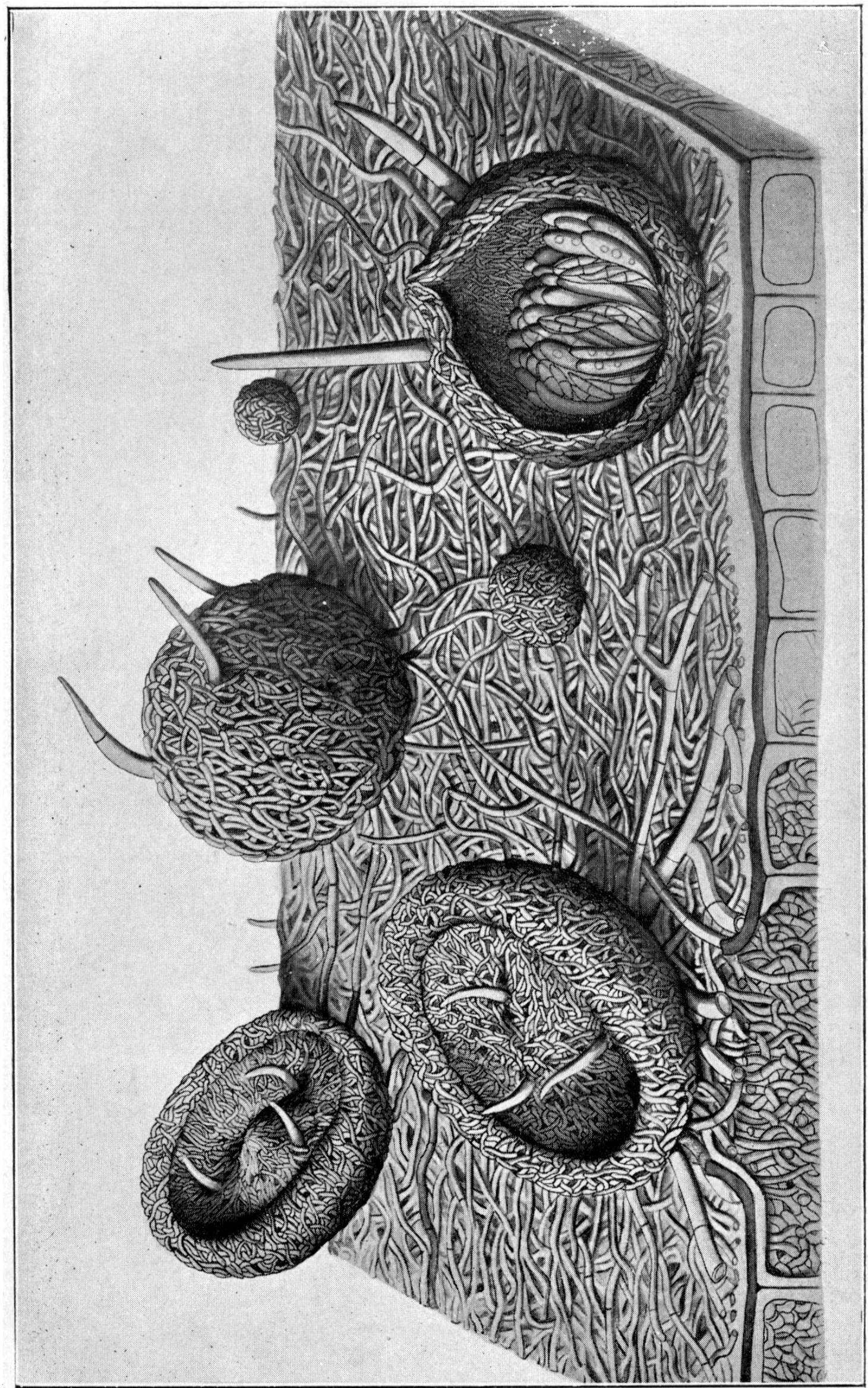




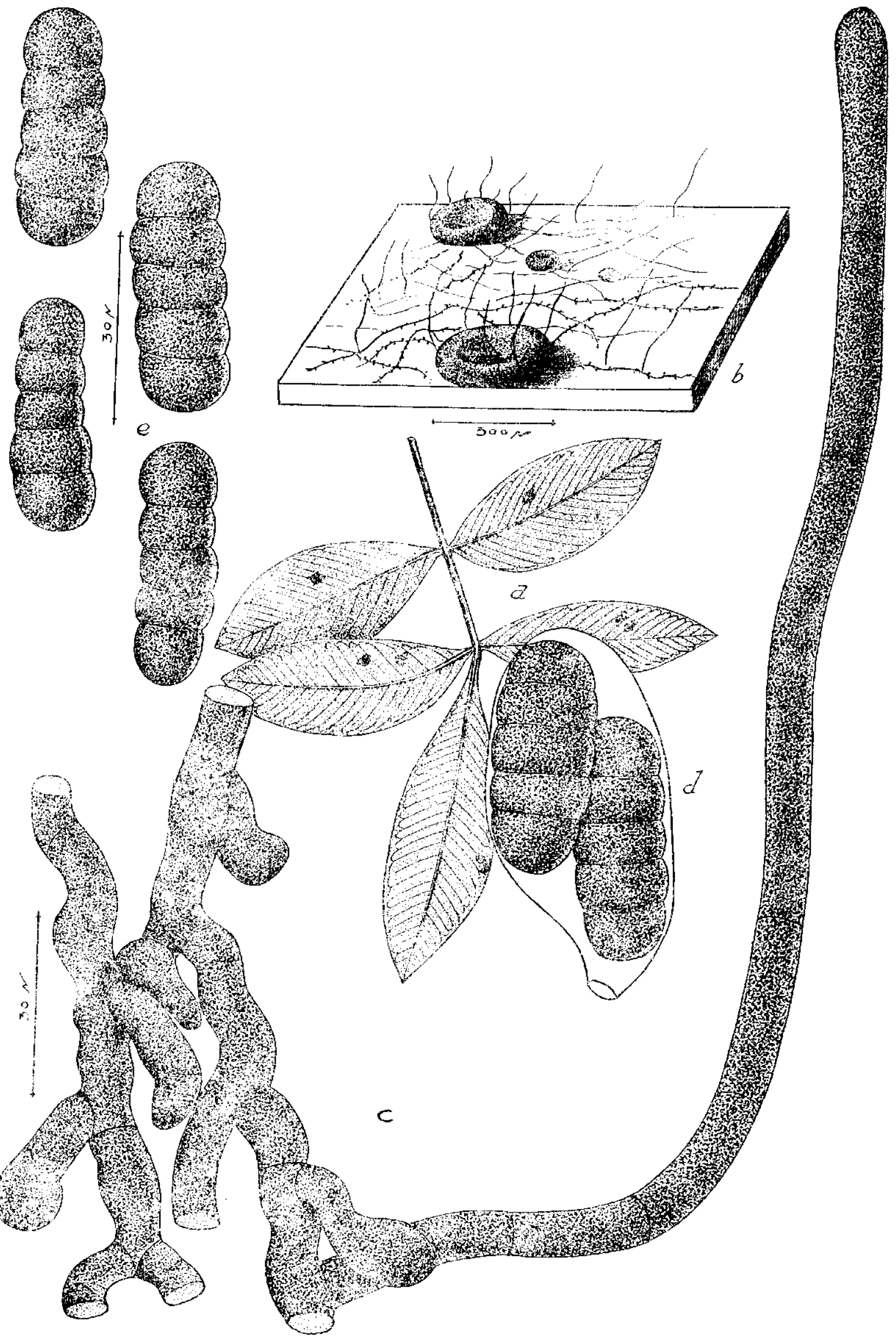


Est. III
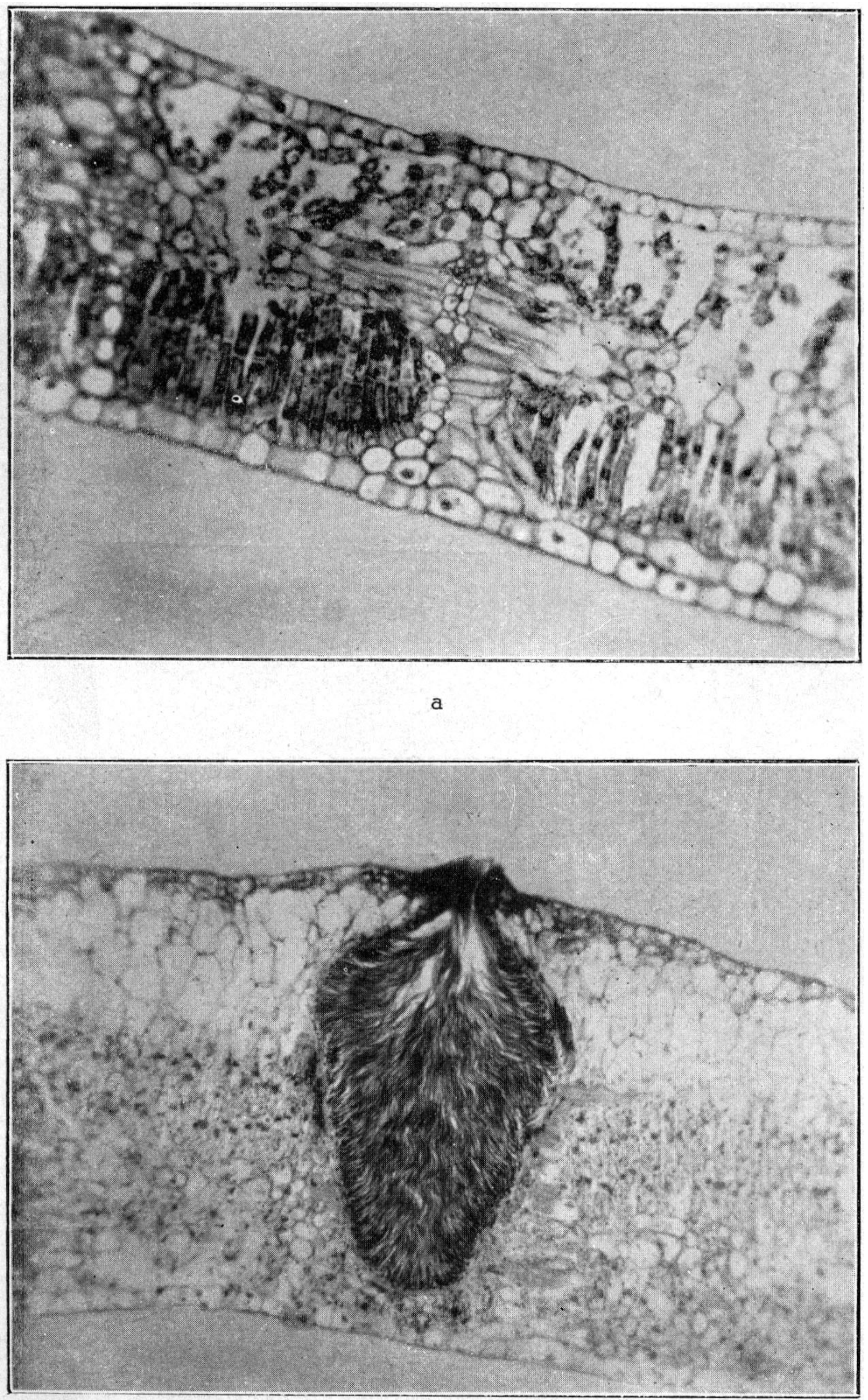

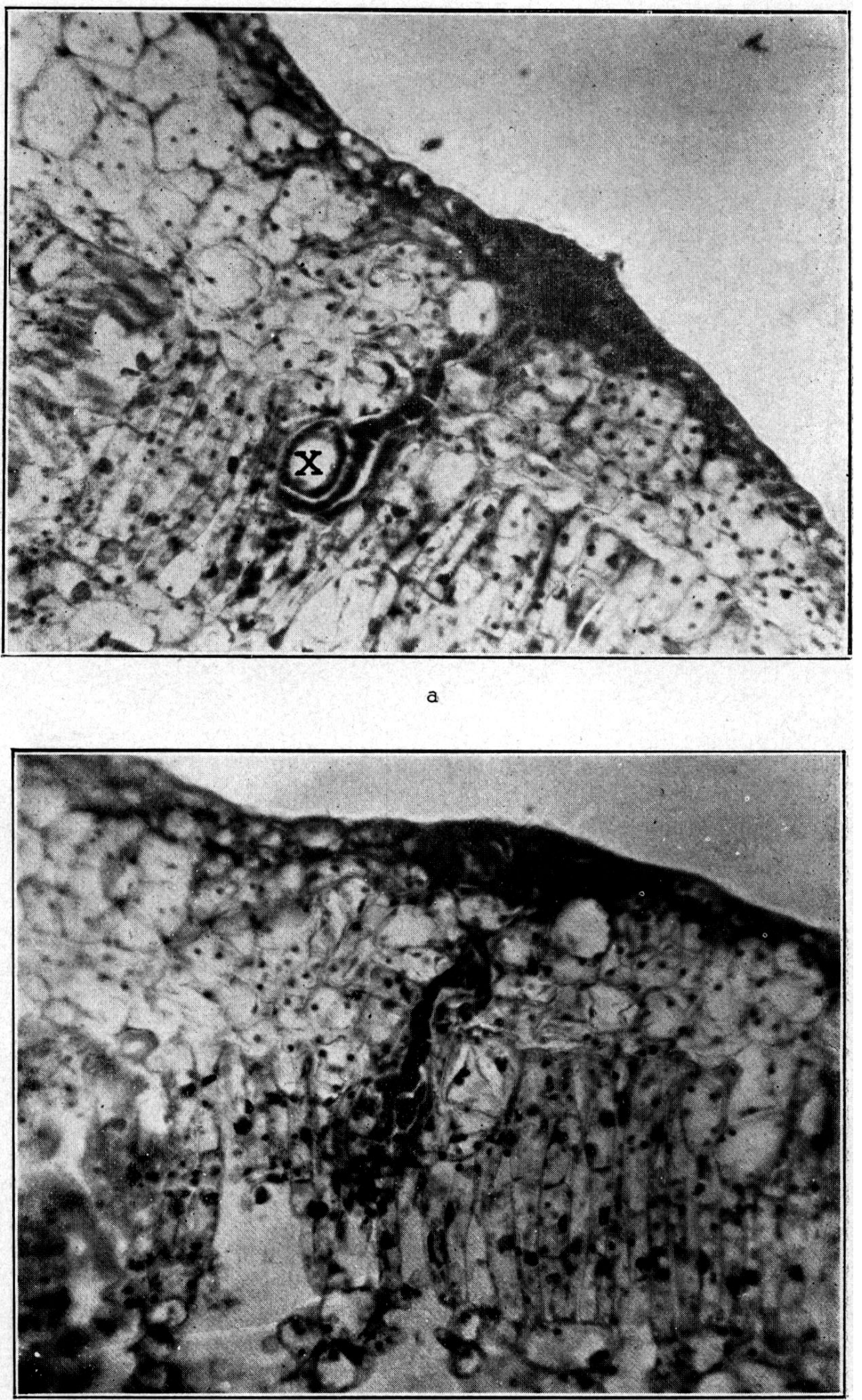
Est. V

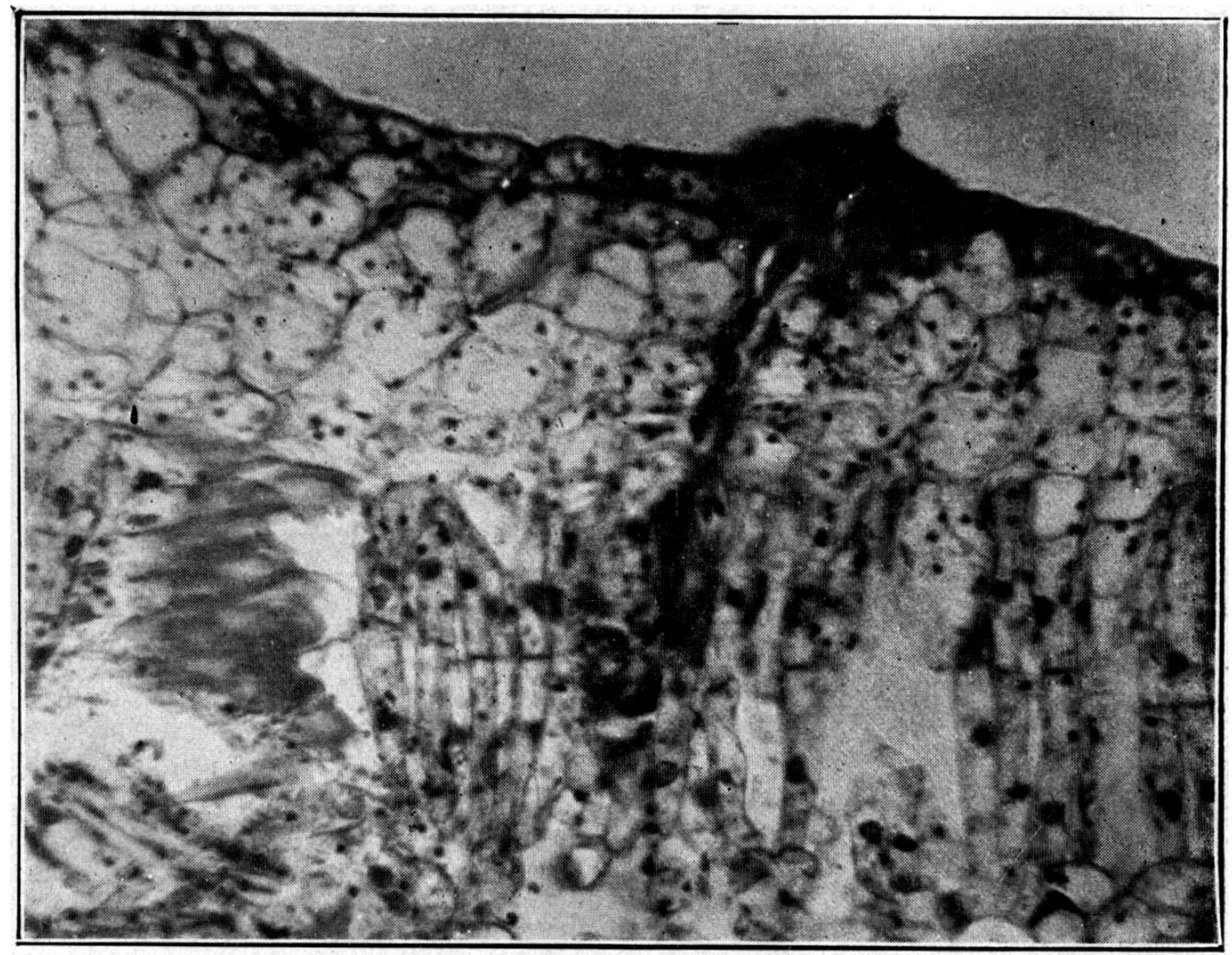

a

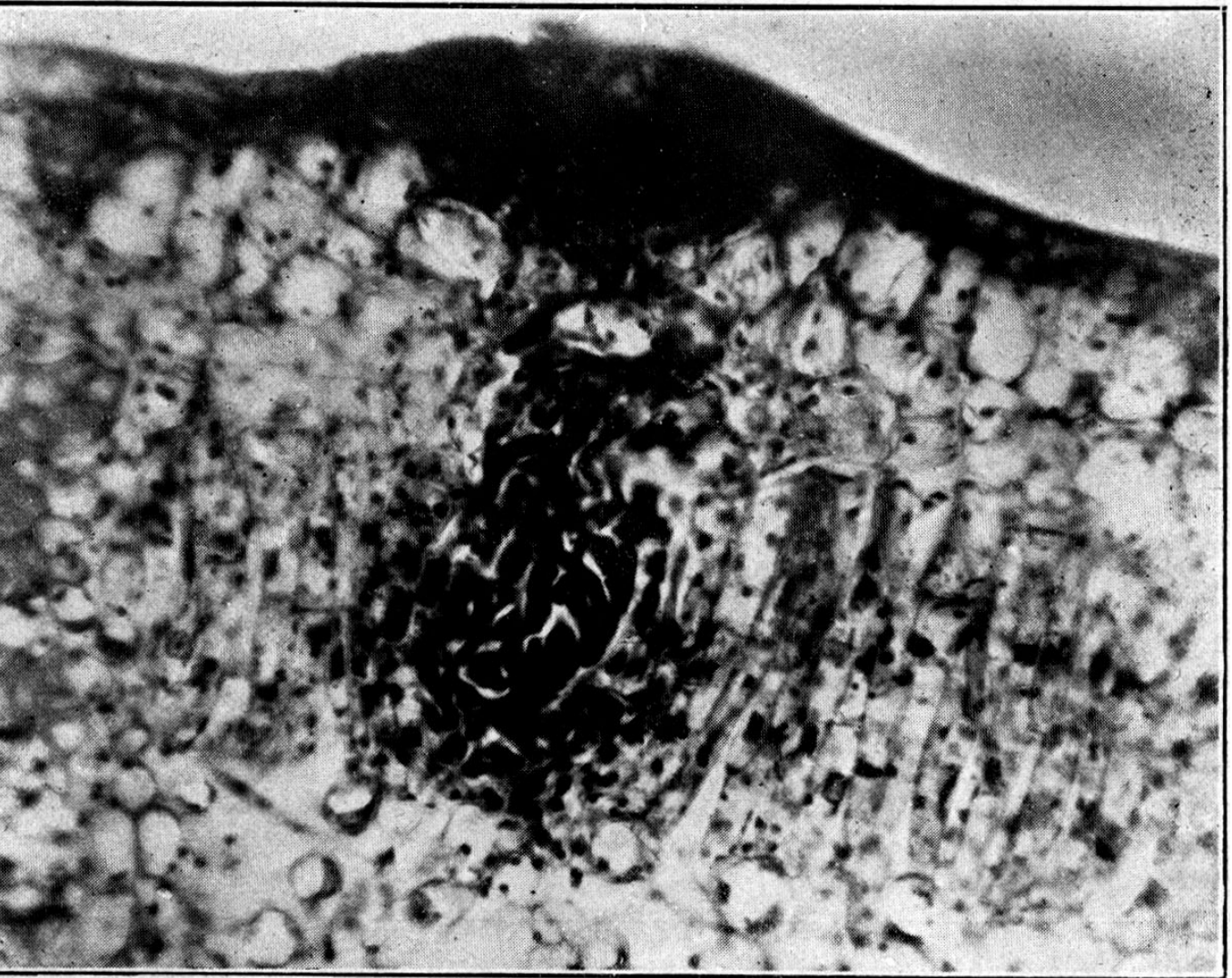


Est. VI

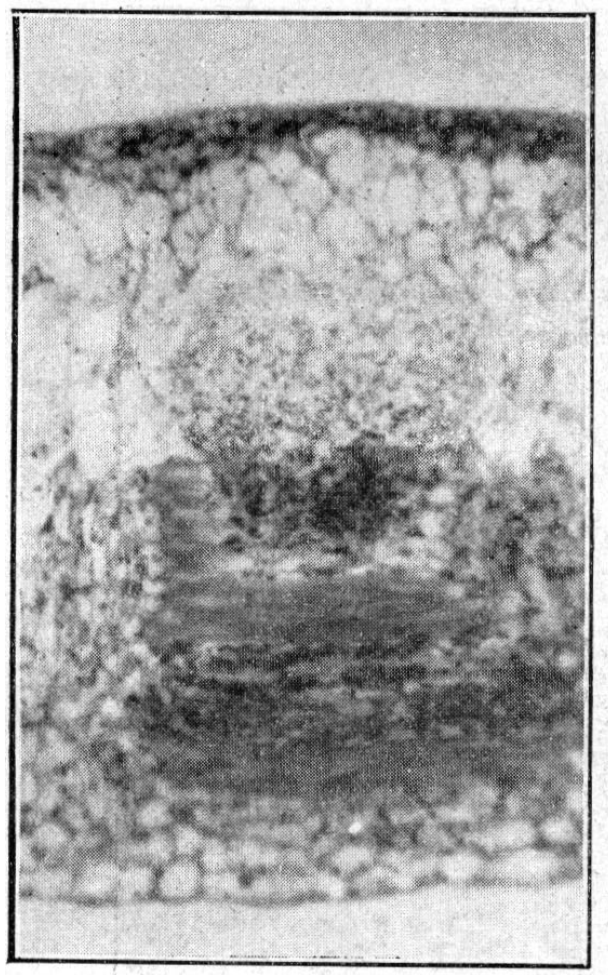

a

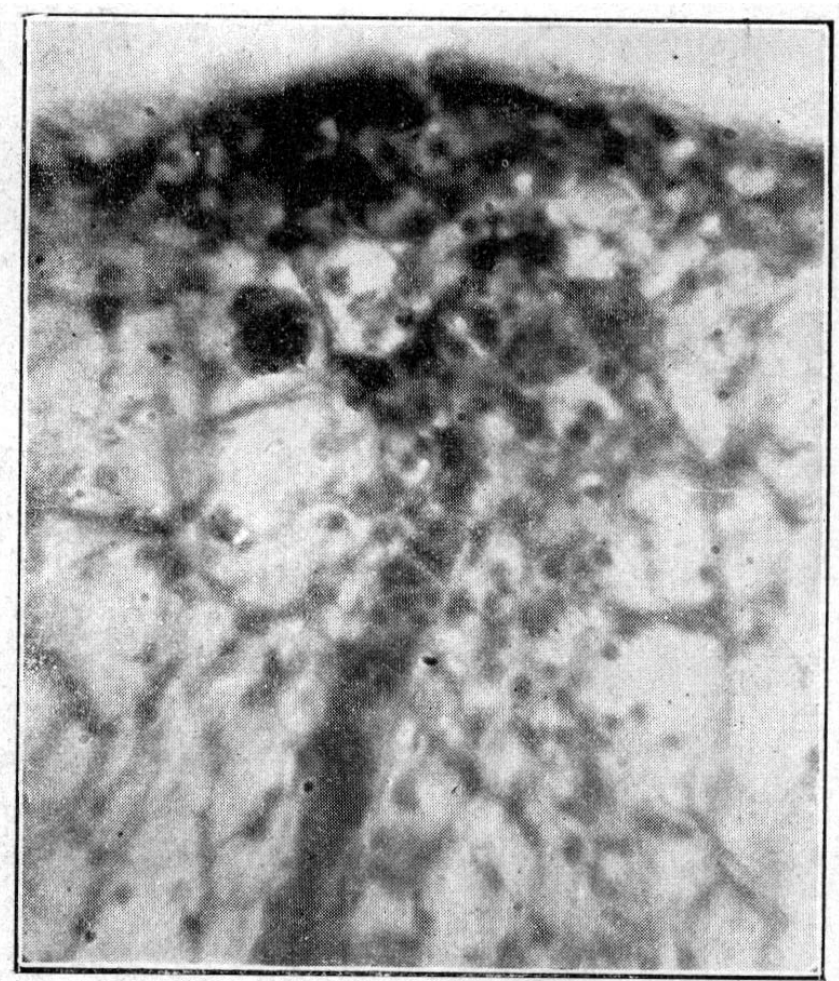

b

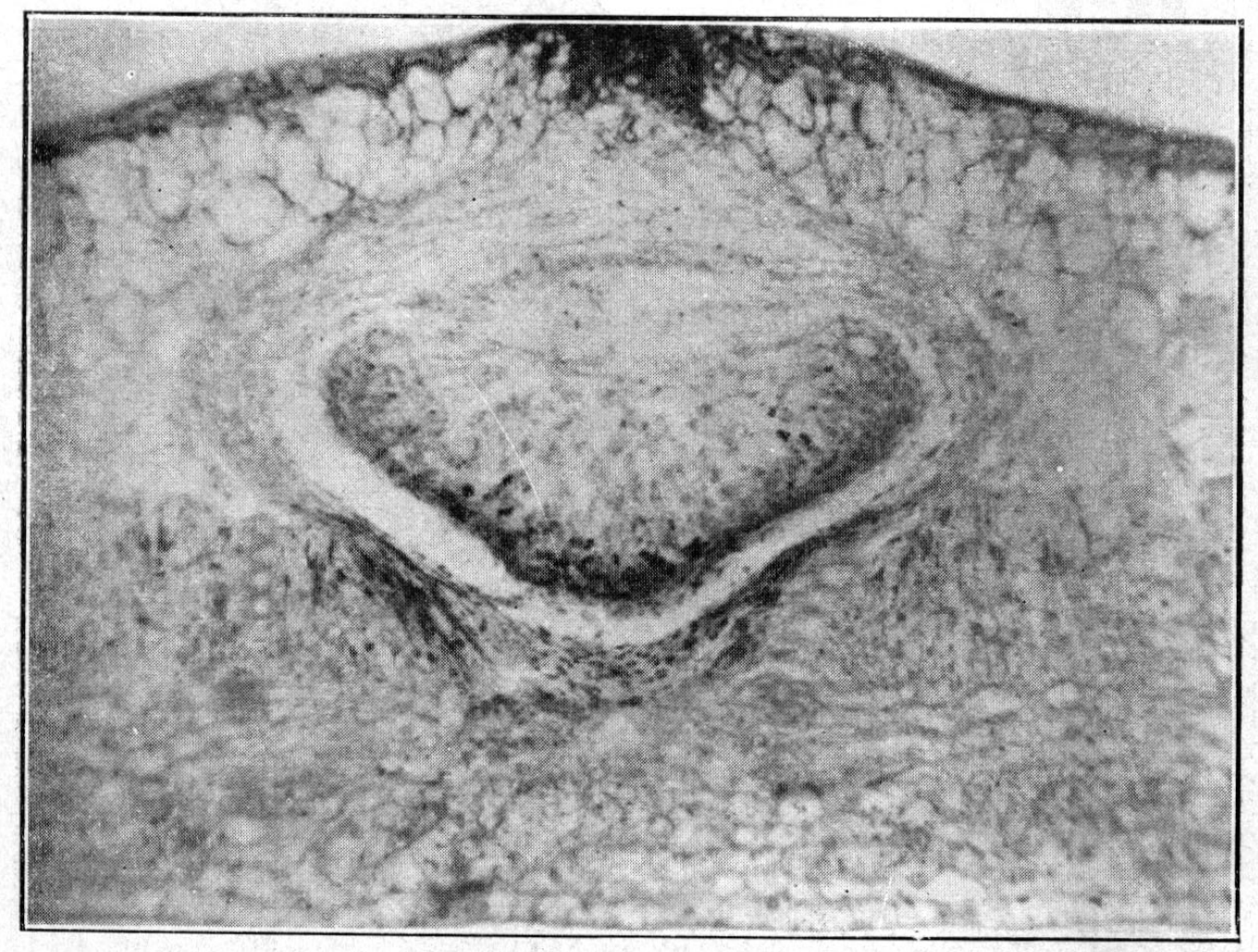


Est. VII

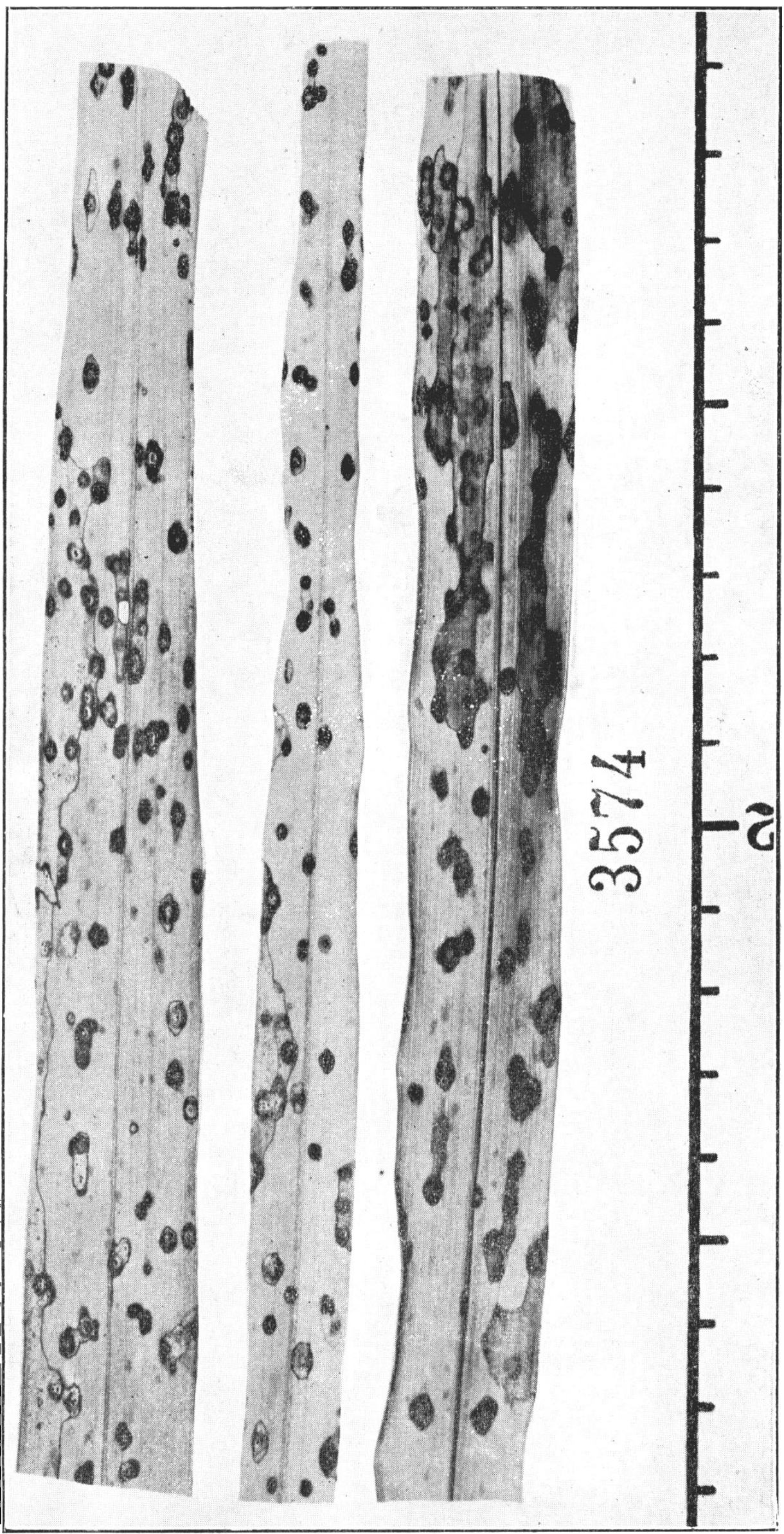


Vol. 3
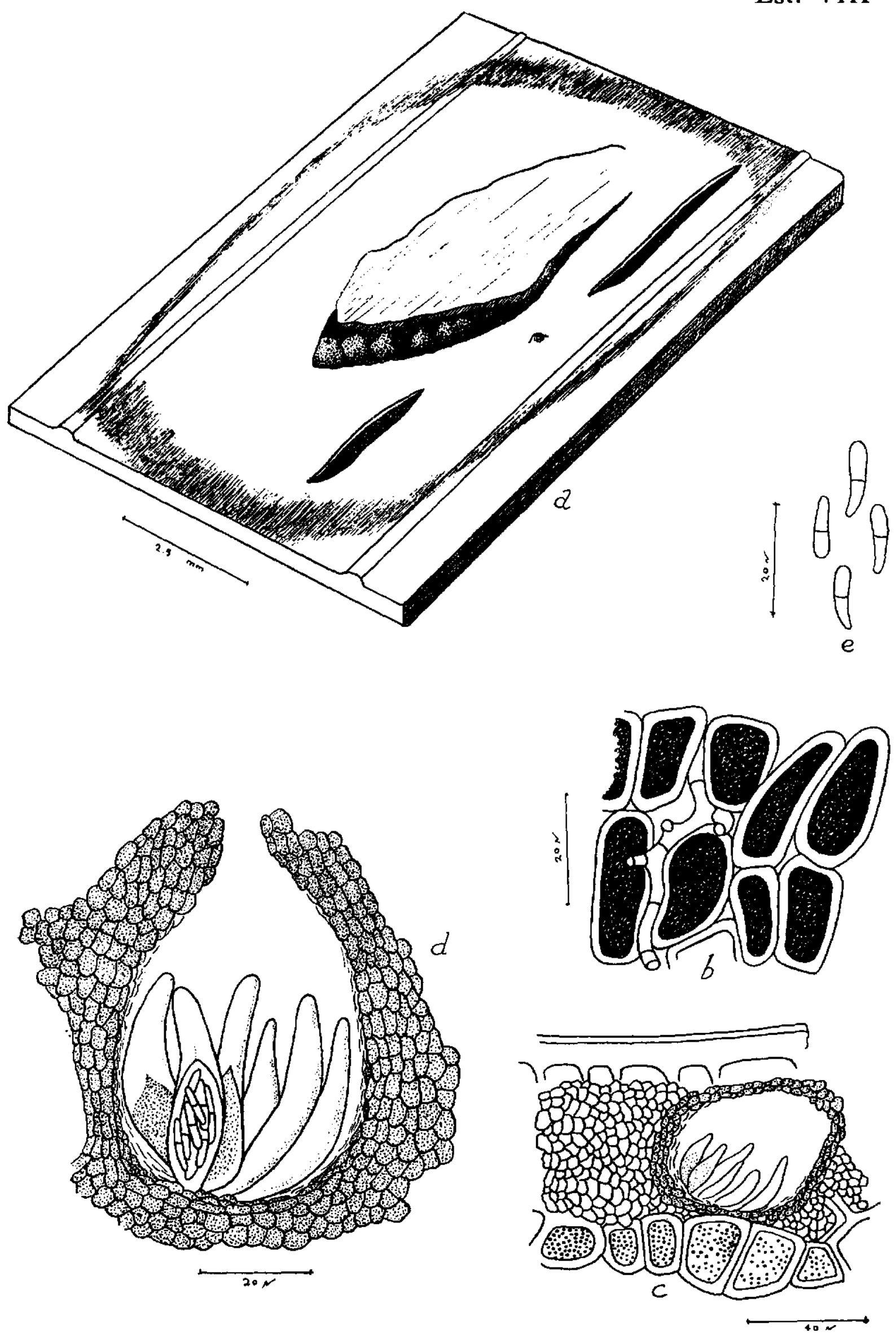
Est. 1X

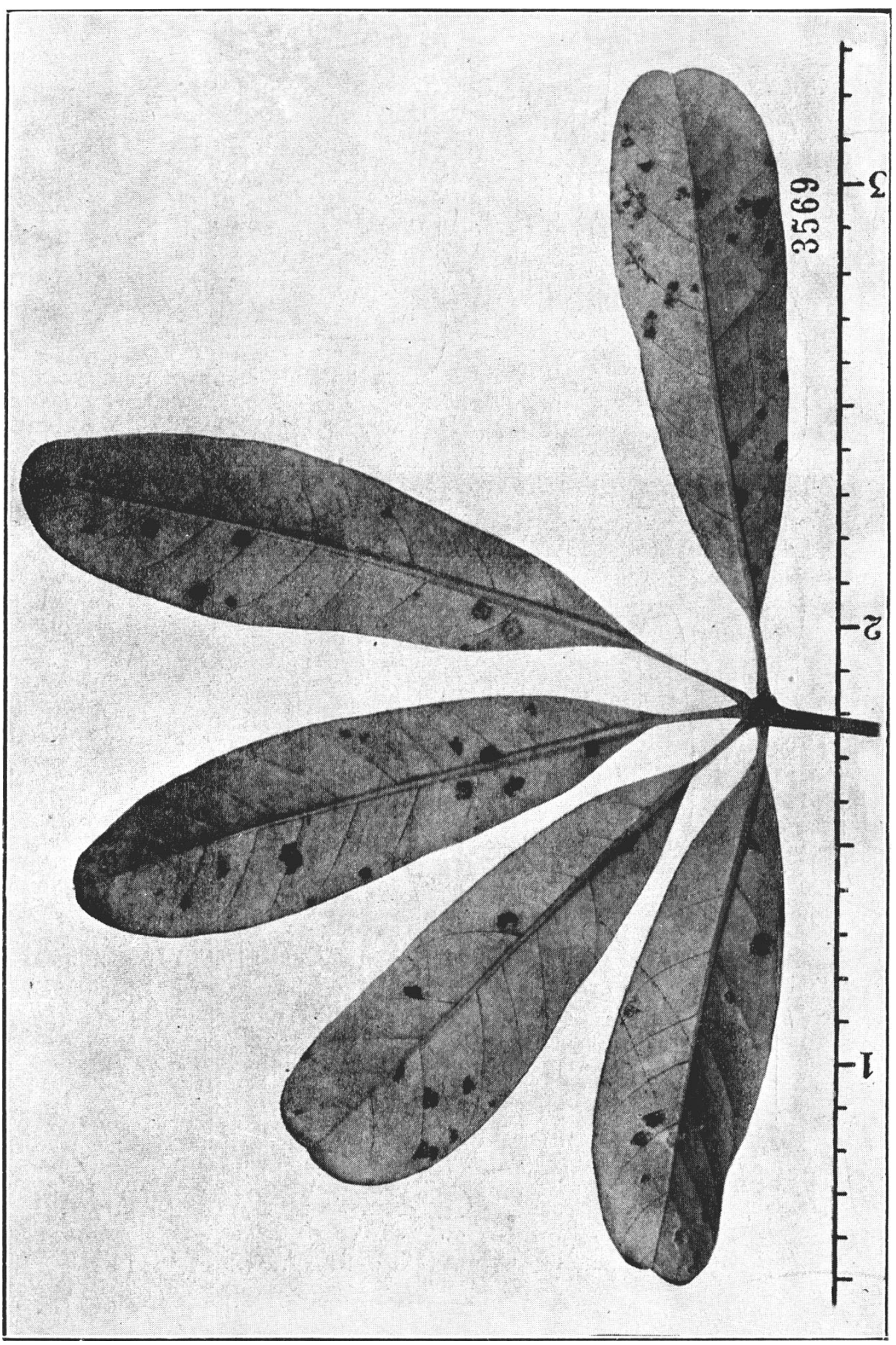


Est. X
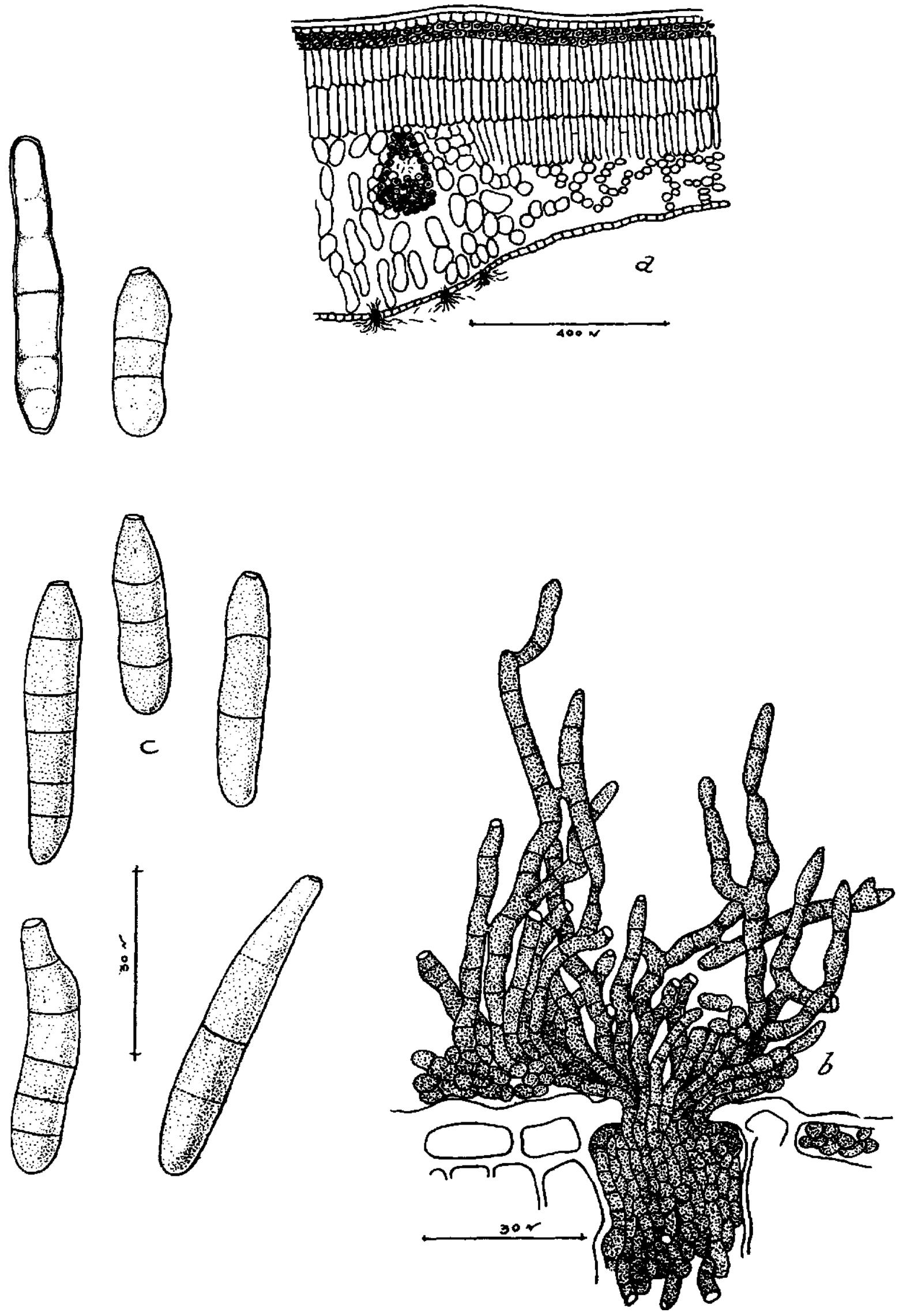